\title{
PEMAKAIAN ONGGOK FERMENTASI DALAM RANSUM TERHADAP PERFORMA AYAM BURAS PERIODE PERTUMBUHAN
}

\author{
E. IRAWATI ${ }^{1}$, MIRZAH $^{2}$, DAN G.CIPTAAN ${ }^{2}$ \\ ${ }^{1}$ Fakultas Pertanian dan PeternakanUniversitas Islam Negeri Sultan Syarif Kasim Riau, \\ ${ }^{2}$ Fakultas Peternakan Universitas Andalas Padang \\ Email : eviirawati2013@gmail.com
}

\begin{abstract}
The aims of this research was to study the effect of using fermented onggok in ransum to native chicken performance. The design used was completely randomized design (CRD) with 5 treatment i.e : $R_{1}(10 \%), R_{2}(15 \%), R_{3}(20 \%), R_{4}(25 \%)$ and $R_{5}(30 \%)$ with 4 replications. The ransum was composed with protein $(18 \%)$ and calorie $(2900 \mathrm{kcal} / \mathrm{kg})$. Result of research shows that using fermented onggok had highly significant effect $(P<0.05)$ towards the feed consumption, body weight gain and feed conversion of buras. It was concluded that using fermented onggok could increase highly body weight at level $15 \%$.
\end{abstract}

Keywords : native chicken, performance, fermented, onggok

\section{PENDAHULUAN}

Ayam buras merupakan ternak yang penting dalam pemenuhan kebutuhan protein hewani masyarakat. Permintaan terhadap daging ayam semakin bertambah seiring dengan meningkatnya penghasilan dan kesadaran penduduk akan pentingnya protein hewani. Dalam mengembangkan usaha ternak ayam buras ditentukan oleh banyak faktor untuk mencapai keberhasilan diantaranya faktor produksi. Pada faktor produksi yang berpengaruh adalah ransum, karena dalam penyediaannya menyita $60-70 \%$ dari total biaya produksi (Siregar dkk., 1980). Ransum berguna untuk memenuhi kebutuhan unggas agar bertahan hidup dan berlangsungnya proses biologi serta mampu bereproduksi. Tingginya biaya ransum karena pakan yang digunakan untuk membuat ransum sebagian besar masih diimpor seperti jagung, bungkil kedelai dan tepung ikan. Untuk mengatasi masalah ini diusahakan mencari sumber bahan pakan yang harganya relatif murah, tetapi dapat memenuhi kebutuhan zat makanan bagi ternak tersebut dan tidak bersaing dengan manusia. Salah satu diantaranya adalah onggok.

Onggok merupakan salah satu limbah padat industri tapioka yang mengandung kadar protein kasar dan lemak kasar rendah sedangkan kadar karbohidratnya tinggi.
Produksi onggok di Sumatera Barat cukup banyak terutama pada daerah produsen ubi kayu seperti Sitiung (PT. Incasi Raya) dapat memproduksi onggok sekitar 10 ton/hari, yang berpotensi mencemari lingkungan (Hellyward dkk., 1999). Untuk meningkatkan kualitas gizi dari limbah padat ini sebaiknya onggok diolah dan selanjutnya dapat dimanfaatkan sebagai pakan unggas. Berdasarkan hasil analisis Laboratorium Teknologi Industri Pakan Fakultas Peternakan Universitas Andalas, 2001 diketahui kandungan zat-zat makanan onggok segar adalah BETN 71,11\%; protein kasar 2,57\%; serat kasar 11,18\%; lemak kasar $0,44 \%$ dan abu 0,94\%. Rendahnya kandungan gizi onggok (protein kasar) menyebabkan pemanfaatannya sebagai bahan penyusun ransum ayam broiler menjadi terbatas, hanya dapat dipakai sampai level 10\% (Efna, 1992).

Untuk meningkatkan kandungan gizi onggok terutama protein kasar perlu dilakukan pengolahan melalui teknologi fermentasi. Bahan pakan yang mengalami proses fermentasi biasanya mempunyai nilai gizi yang lebih baik dibandingkan dengan bahan asalnya. Hal ini disebabkan adanya aktivitas enzim yang dihasilkan oleh kapang. Kapang yang digunakan dalam fermentasi adalah Rhizopus spp. yang mempunyai aktivitas protease dan lipase 
yang kuat di samping menghasilkan enzim amilase dan zat antibiotik terhadap bakteribakteri penyebab toksin selama proses fermentasi (Winarno, 1980).

Irawati (2002) menyatakan pengolahan onggok dengan cara fermentasi dapat meningkatkan kandungan protein kasar Onggok Fermentasi (OF) yaitu 5,17\%. Hasil penelitian Erlina (1993) menunjukkan pemakaian onggok yang difermentasi dengan kapang Rhizopus sp. dalam ransum ayam broiler dapat dipakai sampai level $20 \%$, dimana konsumsi ransum, pertambahan berat badan dan konversi ransum sama dengan ransum yang tidak memiliki onggok fermentasi.

Peningkatan kandungan protein kasar OF ini perlu dilakukan uji coba pada ayam buras. Untuk itu dilakukan penelitian untuk mengetahui batasan pemakaian OF dalam ransum terhadap performa ayam buras periode pertumbuhan.

\section{MATERI DAN METODE}

\section{Waktu dan Tempat}

Penelitian dilaksanakan kandang ternak unggas UPT Fakultas Peternakan Universitas Andalas Padang (Provinsi Sumatera Barat).

\section{Materi}

Ternak percobaan yang digunakan pada penelitian ini adalah ayam buras berumur tiga hari (DOC) campuran jantan dan betina sebanyak 80 ekor.

\section{Ransum Percobaan}

Ransum disusun sendiri dari bahanbahan seperti jagung, dedak halus, bungkil kedelai, bungkil kelapa, tepung ikan, tepung tulang dan OF. Kandungan OF dalam ransum perlakuan yaitu $\mathrm{R}_{1}(10 \% \mathrm{OF})$, $\mathrm{R}_{2}\left(15 \%\right.$ OF), $\mathrm{R}_{3}(20 \% \mathrm{OF}), \mathrm{R}_{4}(25 \%$ OF) dan $\mathrm{R}_{5}$ (30\% OF). Komposisi zat makanan bahan penyusun ransum penelitian dapat dilihat pada Tabel 1. Ransum disusun dengan protein kasar 18\% dan kalori $2900 \mathrm{kkal} / \mathrm{kg}$ (Wizna dan Mirzah, 1992) dan air minum diberikan secara ad libitum.

\section{Kandang dan Perlengkapan}

Kandang yang digunakan pada penelitian ini yaitu kandang box sebanyak 20 unit, setiap unitnya berukuran $75 \times 60 \times$ $50 \mathrm{~cm}$ yang dilengkapi dengan tempat pakan dan minum serta lampu pijar dengan kekuatan 60 watt sebagai alat pemanas dan penerangan. Dalam kandang ditempatkan thermometer dan higrometer untuk mencatat suhu dan kelembaban kandang.

\section{Metode Penelitian}

Rancangan percobaan yang digunakan dalam penelitian ini adalah Rancangan Acak Lengkap (RAL) dengan 5 perlakuan yaitu $R_{1}, R_{2}, R_{3}, R_{4}$ dan $R_{5}$ serta 4 ulangan (Steel \& Torrie, 1993). Setiap ulangan terdiri dari 4 ekor ayam sebagai unit percobaan. Semua data yang diperoleh dianalisis dengan analisis sidik ragam (analysis of variance) dan perbedaan antar perlakuan diuji dengan uji Duncan Multiple Range Test (DMRT) (Steel \& Torrie,1993).

\section{Parameter yang Diukur}

Parameter yang diukur pada penelitian ini adalah

- Konsumsi ransum. Dihitung berdasarkan selisih jumlah ransum yang diberikan dengan jumlah ransum yang tersisa. Pengukuran dilakukan setiap minggu kemudian dijumlahkan untuk mendapatkan jumlah konsumsi ransum selama penelitian (g/ekor)

- Pertambahan bobot badan. Diperoleh dari selisih antara bobot badan akhir dan bobot badan awal setiap minggu selama penelitian (g/ekor)

- Konversi ransum dihitung berdasarkan jumlah ransum yang dikonsumsi selama penelitian dibagi dengan pertambahan bobot badan selama penelitian. 
Tabel 1 : Kandungan zat-zat makanan dan energi termetabolisme bahan pakan penyusun ransum

\begin{tabular}{lccrrrc}
\hline \multicolumn{1}{c}{ Bahan Pakan } & \multicolumn{1}{c}{$\begin{array}{c}\text { PK } \\
(\%)\end{array}$} & $\begin{array}{c}\text { L } \\
(\%)\end{array}$ & \multicolumn{1}{c}{$\begin{array}{c}\text { SK } \\
(\%)\end{array}$} & $\begin{array}{c}\text { Ca } \\
(\%)\end{array}$ & $\begin{array}{c}\text { P } \\
(\%)\end{array}$ & $\begin{array}{c}\text { ME } \\
(\mathrm{Kkal} / \mathrm{kg})\end{array}$ \\
\hline Jagung & 7,86 & 2,77 & 2,29 & 0,49 & 0,19 & 3370 \\
Dedak Halus & 10,58 & 6,28 & 11,74 & 0,44 & 0,20 & 1630 \\
Bungkil Kedelai & 42,67 & 4,53 & 6,86 & 0,47 & 0,19 & 2240 \\
Tepung Ikan & 49,81 & 4,85 & 1,78 & 3,17 & 0,37 & 3080 \\
Tepung Tulang & - & - & - & 29,80 & 12,10 & - \\
OF & 11,40 & 5,17 & 14,33 & 0,07 & 0,20 & 3553 \\
Bungkil Kelapa & 20,64 & 6,45 & 6,45 & 0,19 & 0,29 & 1764 \\
\hline
\end{tabular}

Sumber : Hasil Analisis Laboratorium Gizi Non Ruminansia Faterna Unand (2001).

a.Dihitung berdasarkan rumus NRC (1984)

$$
\operatorname{ME}(\mathrm{Kkal} / \mathrm{kg})=\frac{\left(\sum \text { protein } \times 4.4\right)+\left(\sum \text { lemak } x 8.7\right)+\left(\sum \text { BETN } \times 4.0\right)}{100} \times 1000
$$

Tabel.2 : Susunan ransum perlakuan dan kandungan zat-zat makanan serta Energi Metabolisme ransum penelitian $(\%)$

\begin{tabular}{lrrrrr}
\hline Bahan Pakan & \multicolumn{1}{c}{$\mathrm{R} 1$} & $\mathrm{R} 2$ & $\mathrm{R} 3$ & $\mathrm{R} 4$ & \multicolumn{1}{c}{$\mathrm{R} 5$} \\
\hline Jagung & 48,21 & 43,25 & 38,04 & 33,20 & 28,00 \\
Dedak & 13,99 & 14,36 & 14,97 & 15,20 & 16,00 \\
Bungkil kedelai & 7,00 & 7,00 & 7,05 & 7,11 & 6,00 \\
Tepung ikan & 16,30 & 15,89 & 15,44 & 14,99 & 15,50 \\
Tepung tulang & 2,00 & 2,00 & 2,00 & 2,00 & 2,00 \\
Onggok fermentasi & 10,00 & 15,00 & 20,00 & 25,00 & 30,00 \\
Bungkil kelapa & 2,00 & 2,00 & 2,00 & 2,00 & 2,00 \\
Premix & 0,50 & 0,50 & 0,50 & 0,50 & 0,50 \\
\hline Total & 100,00 & 100,00 & 100,00 & 100,00 & 100,00 \\
\hline Protein (\%) & 17,93 & 17,94 & 17,97 & 17,98 & 18,01 \\
Lemak (\%) & 3,84 & 3,96 & 4,10 & 4,22 & 4,33 \\
Serat Kasar (\%) & 4,95 & 5,59 & 6,25 & 6,88 & 7,01 \\
Kalsium (\%) & 1,43 & 1,42 & 1,39 & 1,36 & 1,32 \\
Fosfor (\%) & 0,46 & 0,46 & 0,46 & 0,46 & 0,47 \\
ME (Kkal/kg) & 2902 & 2906 & 2906 & 2911 & 2912 \\
\hline
\end{tabular}

\section{HASIL DAN PEMBAHASAN}

Rataan konsumsi ransum, pertambahan buras selama penelitian dapat dilihat pada Tabel 3. bobot badan dan konversi ransum ayam

Tabel 3. Rataan konsumsi ransum, pertambahan bobot badan dan konversi ransum ayam buras per ekor per minggu tiap perlakuan selama penelitian

\begin{tabular}{cccc}
\hline Perlakuan & $\begin{array}{c}\text { Konsumsi } \\
\text { Ransum }(\mathrm{g})\end{array}$ & $\begin{array}{c}\text { Pertambahan } \\
\text { Bobot badan }(\mathrm{g})\end{array}$ & Konversi ransum \\
\hline $\mathrm{R}_{1}$ & $84,14^{\mathrm{a}}$ & $18,85^{\mathrm{a}}$ & $4,48^{\mathrm{a}}$ \\
$\mathrm{R}_{2}$ & $85,56^{\mathrm{a}}$ & $20,68^{\mathrm{c}}$ & $4,14^{\mathrm{c}}$ \\
$\mathrm{R}_{3}$ & $84,91^{\mathrm{a}}$ & $19,92^{\mathrm{c}}$ & $4,26^{\mathrm{ac}}$ \\
$\mathrm{R}_{4}$ & $84,63^{\mathrm{a}}$ & $19,20^{\mathrm{ab}}$ & $4,41^{\mathrm{ac}}$ \\
$\mathrm{R}_{5}$ & $82,92^{\mathrm{b}}$ & $16,62^{\mathrm{d}}$ & $4,98^{\mathrm{b}}$ \\
$\mathrm{SE}^{*}$ & 0,53 & 0,33 & 0,10 \\
\hline
\end{tabular}

Keterangan : KR Berbeda Nyata $(\mathrm{P}<0,05), \mathrm{PBB}$ dan KV Berbeda Sangat Nyata $(\mathrm{P}<0,01)$ 
Hasil analisis keragaman menunjukkan penggunaan OF $10-30 \%$ dalam ransum memberikan pengaruh yang berbeda nyata $(\mathrm{P}<0,05)$ terhadap konsumsi ransum dan berbeda sangat nyata $(\mathrm{P}<0,01)$ terhadap pertambahan bobot badan dan konversi ransum ayam buras.

Berbeda tidak nyatanya $(\mathrm{P}>0,05)$ konsumsi ransum $R_{1}, R_{2}, R_{3}$, dan $R_{4}$ disebabkan perbandingan energi dan protein untuk masing-masing perlakuan adalah seimbang. Hal ini menunjukkan perlakuan fermentasi dapat meningkatkan kualitas onggok. Wahju (1992) menyatakan perbandingan tingkat energi dan protein akan mempengaruhi konsumsi ransum, meningkatnya energi dan protein tetap dan sebaliknya protein meningkat dan energi tetap akan mempengaruhi konsumsi ransum.

Penyebab lain berbeda tidak nyatanya $(\mathrm{P}>0,05)$ konsumsi ransum $\mathrm{R}_{1}, \mathrm{R}_{2}$, $\mathrm{R}_{3}$, dan $\mathrm{R}_{4}$ disebabkan oleh palatabilitas, bentuk fisik, aroma serta kesegaran ransum pada masing-masing perlakuan sama walaupun tingkat penggunaan $O F$ dalam ransum berbeda. Sesuai pendapat Siregar dkk. (1980) bahwa palatabilitas, kesegaran ransum merupakan faktor yang juga menentukan jumlah ransum yang dikonsumsi dan ransum yang mempunyai cita rasa yang disenangi akan lebih banyak dikonsumsi dan akan dicerna lebih baik.

Berbeda nyatanya konsumsi ransum $R_{5}$ dengan $R_{1}, R_{2}, R_{3}$ dan $R_{4}$ disebabkan peningkatan level pemakaian OF dalam ransum sehingga warna ransum semakin gelap (coklat kehitam-hitaman) dan tekstur ransum menjadi lebih halus (mash). Sementara ayam lebih menyukai makanan berbutir dari pada berbentuk tepung. Sesuai dengan pendapat Wahju (1992) bahwa ternak unggas lebih menyukai ransum yang berbentuk butiran dari pada berbentuk tepung. Ditambahkan oleh Rasyaf (1989) bahwa warna dan bentuk ransum mempengaruhi konsumsi ternak unggas, dimana ransum yang mempunyai warna terang akan disenangi dan lebih banyak dikonsumsi.

Penyebab lain terjadinya penurunan konsumsi ransum ayam buras pada perlakuan $R_{5}$ adalah kurangnya vitamin $B_{1}$ pada ransum. Dengan semakin banyaknya pemakaian $\mathrm{OF}$ dalam ransum maka penggunaan jagung dan bungkil kedelai (bahan makanan yang kaya thiamin) semakin sedikit akibatnya kandungan vitamin $B_{1}$ dalam ransum berkurang, diketahui bahwa vitamin $B_{1}$ dapat merangsang nafsu makan pada ternak ayam. Anggorodi (1985) menyatakan dari semua zat-zat makanan vitamin $\mathrm{B}_{1}$ mempunyai pengaruh paling nyata terhadap nafsu makan. Hewan yang thiaminnya rendah akan segera memperlihatkan anoreksia (nafsu makan menurun) yang parah.

Tingginya pertambahan bobot badan pada ternak yang mendapat perlakuan ransum OF taraf $15 \%$ dan $20 \%$ memberikan petunjuk bahwa ransum memiliki palatabilitas yang baik dari pengaruh fermentasi dibandingkan perlakuan $\mathrm{R}_{1}$ dan $\mathrm{R}_{4}$ sehingga banyak dikonsumsi selain itu karena ransum ini memiliki nilai gizi dan energi yang baik sehingga dapat dicerna dan dimanfaatkan sebaik-baiknya oleh ternak untuk memicu pertumbuhan. Hal ini sesuai pendapat Winarno (1980) bahwa ransum yang difermentasi akan meningkatkan palatabilitas dan konsumsi sehingga efisiensi penggunaan ransum tinggi.

Penyebab lain tingginya pertambahan bobot badan pada perlakuan $R_{2}$ dan $R_{3}$ dibandingkan perlakuan $\mathrm{R}_{1}$ dan $\mathrm{R}_{4}$ adalah tingginya kualitas protein pada perlakuan tersebut sehingga terjadi peningkatan retensi nitrogen. Protein merupakan salah satu zat nutrisi dalam ransum sehingga jumlah protein yang dikonsumsi tergantung kepada banyaknya konsumsi ransum. Siregar dkk (1980) menyatakan jumlah konsumsi protein akan menentukan pertambahan bobot badan. 
Rendahnya pertambahan bobot badan pada perlakuan $\mathrm{R}_{5}$ disebabkan semakin tingginya kandungan serat kasar ransum mengakibatkan rendahnya daya cerna sehingga pertambahan bobot badan menurun. Sesuai pendapat Tillman dkk. (1984) bahwa serat kasar dalam ransum mempunyai pengaruh terbesar terhadap daya cerna, semakin tinggi serat kasar maka daya cerna semakin menurun, konsumsi ransum juga menurun akibatnya pertambahan bobot badan juga menurun.

Berbeda tidak nyatanya konversi ransum $R_{2}, R_{3}$ dan $R_{4}$ disebabkan oleh kualitas ransum yang baik dan seimbangnya komposisi zat-zat makanan sesuai pendapat Card dan Nesheim ( 1972) bahwa besar kecilnya nilai konversi ransum dipengaruhi oleh kualitas ransum dan kemampuan ayam buras mengubah ransum yang dikonsumsi menjadi daging. Ransum yang berkualitas dengan komposisi zat makanan yang seimbang meningkatkan nilai efisiensi ransum. Ditambahkan oleh Soeharsono (1976) bahwa konversi ransum tidak hanya menggambarkan efek fisiologis dalam memanfaatkan unsur gizi, melainkan juga mempunyai nilai ekonomis yang menentukan bagi kepentingan pengusaha. Semakin kecil angka konversi berarti semakin baik tingkat pemberian ransum.

Tingginya angka konversi ransum pada perlakuan $R_{5}$ disebabkan adanya perbedaan jumlah ransum yang dikonsumsi dengan pertambahan bobot badan yang dihasilkan. Selain itu juga disebabkan rendahnya konsumsi ransum sehingga makanan yang dikonversikan untuk pertumbuhan menjadi sedikit. Scott et al. (1982) menyatakan besarnya nilai konversi ransum ditentukan oleh banyaknya ransum yang dikonsumsi dan pertambahan bobot badan yang dihasilkan.

\section{KESIMPULAN}

Pemakaian OF dalam ransum ayam buras periode pertumbuhan menghasilkan pertambahan bobot badan tertinggi pada level $15 \%$.

\section{DAFTAR PUSTAKA}

Anggorodi, R. 1985. Ilmu Makanan Ternak Unggas. Penerbit Universitas Indonesia. Jakarta.

Card. L. E and M. C. Nesheim. 1972 Poultry Production. $11^{\text {th }}$ Ed. Lea and Febinger, Philodelphia

Efna, Y. 1992. Pengaruh Pemakaian Ampas Tapioka dalam Ransum terhadap Performans Ayam Broiler. Skripsi Fakultas Peternakan Universitas Andalas. Padang.

Erlina. 1993. Pemakaian Onggok Fermentasi dalam Ransum Ayam Broiler. Skripsi Fakultas Peternakan Universitas Andalas Padang.

Hellyward. J., Mirzah dan E. Rossy. 1999. Penggunaan Onggok dan Limbah Industri Sawit dalam Usaha Ternak Sapi Potong. Laporan Penelitian. Fakultas Peternakan Universitas Andalas. Padang.

Irawati. E. 2002. Pengaruh Pemakaian Onggok Fermentasi dengan Kapang Rhizopus spp. dalam Ransum terhadap Performa Ayam Buras Periode Pertumbuhan. Skripsi Fakultas Peternakan Universitas Andalas Padang.

Rasyaf, M. 1989. Memelihara Ayam Buras. Kanisius. Yogyakarta.

National Research Council. 1984. Nutrient Requirementts of Poultry. $7^{\text {th }}$ Ed. National Academy of Science. Washington.

Scott, M. L. C Nasheim and R. J. Young. 1982.

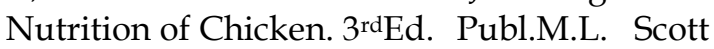
and Associates. Ithaca, New York.

Siregar, A. P., M. Sabrani dan P. Suroprawiro. 1980. Teknik Beternak Ayam Pedaging di Indonesia. Margie Group. Jakarta.

Soeharsono. 1976. Respon Ayam Broiler terhadap Berbagai Kondisi Lingkungan. Disertasi. Universitas Padjajaran. Bandung.

Steel, R. G. D, dan H. Torrie. 1993. Prinsip dan Prosedur Statistika Suatu Pendekatan Biometrik. Penerbit PT. Gramedia Pustaka Utama. Jakarta. 
Tillman, A.D., H. Hartadi, S. Reksohadiprodjo., S. Prawirokusumo dan S. Lebdosoekojo, 1984. Ilmu Pakan Ternak Dasar. Universitas Gajah Mada, Yogyakarta.

Wahju, J. 1992. Ilmu Nutrisi Unggas. Cet ke-3. Gadjah Mada University Press. Yogyakarta.
Wizna dan Mirzah. 1992. Penentuan Kebutuhan Protein Melalui Efisiensi Penggunaan Protein pada Ayam Buras. Laporan Penelitian. Fakultas Peternakan. Universitas Andalas. Padang.

Winarno, F. G. dan S. Fardiaz. 1980. Pengantar Ilmu Teknologi Pangan. PT. Gramedia Pustaka Utama. Jakarta. 